University of Nebraska - Lincoln

DigitalCommons@University of Nebraska - Lincoln

Faculty Papers and Publications in Animal

Science

Animal Science Department

2010

\title{
Nutritional and management methods to decrease nitrogen losses from beef feedlots
}

\author{
Galen Erickson \\ University of Nebraska-Lincoln, gerickson4@unl.edu \\ Terry Klopfenstein \\ Universitiy of Nebraska--Lincoln, tklopfenstein1@unl.edu
}

Follow this and additional works at: https://digitalcommons.unl.edu/animalscifacpub

Part of the Animal Sciences Commons

Erickson, Galen and Klopfenstein, Terry, "Nutritional and management methods to decrease nitrogen losses from beef feedlots" (2010). Faculty Papers and Publications in Animal Science. 707.

https://digitalcommons.unl.edu/animalscifacpub/707

This Article is brought to you for free and open access by the Animal Science Department at DigitalCommons@University of Nebraska - Lincoln. It has been accepted for inclusion in Faculty Papers and Publications in Animal Science by an authorized administrator of DigitalCommons@University of Nebraska - Lincoln. 


\title{
Nutritional and management methods to decrease nitrogen losses from beef feedlots ${ }^{1}$
}

\author{
G. Erickson ${ }^{2}$ and T. Klopfenstein
}

Department of Animal Science, University of Nebraska, Lincoln 68583-0908

\begin{abstract}
Nitrogen losses from open beef feedlots are a concern. Methods that decrease volatilization losses will lead to greater manure $\mathrm{N}$, which is likely to be beneficial in open lot beef operations. Twelve or more pens were dedicated to $\mathrm{N}$ research whereby $\mathrm{N}$ intake, retention, and excretion were quantified and a mass balance conducted using manure, runoff, soil balance, and loss quantities. The objective was to decrease $\mathrm{N}$ volatilization losses or increase manure $\mathrm{N}$ or both. Dietary $\mathrm{CP}$ affects $\mathrm{N}$ excretion and $\mathrm{N}$ volatilization losses. Four experiments across 2 yr compared industry average CP $(13 \%)$ to diets that were phase-fed to not exceed protein requirements (12.1 to $10.9 \%)$. Phase-fed cattle excreted 12 to $21 \%$ less $\mathrm{N}(P<0.01)$, and $\mathrm{N}$ volatilization losses were reduced 15 to $33 \%(P<0.01)$. In 2 other experiments, phase-fed diets were formulated to recycle undegradable intake protein. Steer G:F was similar $(P=0.18)$ or improved $(P=0.09)$, whereas $\mathrm{N}$ excretion and $\mathrm{N}$ volatilization losses tended to be reduced $(P<0.11)$ and $\mathrm{N}$ in manure was not affected $(P>0.35)$ compared with cattle fed $13 \%$ CP. Feeding less protein did not affect manure $\mathrm{N}$, indicating manure $\mathrm{N}$ from open lots is related to other factors.
\end{abstract}

A series of experiments evaluated increasing $\mathrm{OM}$ on the pen surface to increase $\mathrm{N}$ in manure. Feeding less digestible diets using fiber increased manure $\mathrm{N}(P<$ $0.01)$ and decreased $(P<0.10) \mathrm{N}$ volatilization losses in 2 experiments conducted from November to May, but did not affect $(P>0.30)$ manure $\mathrm{N}$ or volatilization losses during 2 summer experiments. Adding bedding (i.e., $\mathrm{OM}$ ) increased manure $\mathrm{N}$ in the winter as well. Another method evaluated was increasing pen cleaning frequency, which decreased $\mathrm{N}$ volatilization losses by 19 to $44 \%$ and increased manure $\mathrm{N}$ by 26 to $41 \%$ across 3 experiments. Other methods, such as acidifying manure by manipulating dietary cation anion difference, clinoptilite zeolite clay addition, and feeding different amounts of by-products had variable impacts on $\mathrm{N}$ volatilization losses. No treatments markedly affected runoff $\mathrm{N}$, which is $<5 \%$ of excreted N. Dietary protein affects $\mathrm{N}$ volatilization losses but not manure N. Other factors, such as OM on the pen surface, affect manure N. Cleaning manure frequently, which decreases exposure of manure $\mathrm{N}$ to air, decreases volatilization losses. Treatments should be evaluated across seasons due to seasonal effects.

Key words: beef cattle, feedlot, loss, nitrogen, nutrient management

(C)2010 American Society of Animal Science. All rights reserved.

J. Anim. Sci. 2010. 88(E. Suppl.):E172-E180 doi:10.2527/jas.2009-2358

\section{INTRODUCTION}

Environmental issues related to beef feedlot production are becoming increasingly important to producers

\footnotetext{
${ }^{1}$ Based on an invited presentation, as a recipient of an ASAS Early Career Achievement Award, at the Joint Annual Meeting, July 12 to 16, 2009, Montreal, Canada. The symposium was sponsored, in part, by the ASAS Foundation, with publication sponsored by the Journal of Animal Science and the American Society of Animal Science. A contribution of the University of Nebraska Agricultural Research Division, supported in part by funds provided through the Hatch Act.

${ }^{2}$ Corresponding author: geericks@unlnotes.unl.edu

Received July 31, 2009.

Accepted January 5, 2010.
}

and consumers. Feedlots continue to increase in size and concentration due to economics, and consequently the manure nutrients are becoming concentrated in local areas. Currently, the main concern is with open-lot soil-surfaced feedlot production typical of the Plains states.

There are different nutrients such as $\mathrm{N}, \mathrm{P}, \mathrm{OM}, \mathrm{NaCl}$, and $\mathrm{K}$ that receive attention when displaced into surface water, ground water, or cropping acres. Nitrogen and $\mathrm{P}$ are quite different concerns. Two concerns when $\mathrm{N}$ volatilization occurs as $\mathrm{NH}_{3}$ from manure on the pen surface are 1) formation of particulate matter $\left(\mathrm{PM}_{2.5}\right)$ that negatively affects human health (US EPA, 2004), and 2) enrichment of ecosystems (soil, water, etc) when $\mathrm{N}$ is eventually deposited from air during rainfall. 


\section{FATE OF N}

Nitrogen excretion by cattle fed high-concentrate diets is either in urine as urea (60 to $80 \%$ of total N excretion) or in feces. Similar to metabolism in the rumen, urea can be rapidly hydrolyzed to $\mathrm{CO}_{2}$ and $\mathrm{NH}_{4}$ by urease. Therefore, urinary $\mathrm{N}$ can contribute to the pool of $\mathrm{NH}_{3}$ volatilizing from open-dirt feedlots. Fecal $\mathrm{N}$ may contribute as well, but presumably at a much slower rate. Evidence indicates that urinary $\mathrm{N}$ may be entirely converted to $\mathrm{NH}_{4}$ within hours (Mobley et al., 1995). Another important consideration in amount of volatilized $\mathrm{N}$ is the relative proportion of $\mathrm{NH}_{3}$ to $\mathrm{NH}_{4}$. The relative amount of these 2 compounds is an equilibrium reaction with a pKa of approximately 9.3. Therefore, $\mathrm{pH}$, concentration of $\mathrm{NH}_{4}$, and temperature can influence the pool of $\mathrm{NH}_{3}$ that volatilizes. Concentration of $\mathrm{NH}_{3}$ can influence the equilibrium reaction as well, but continuously converts from the liquid phase to gaseous state, thereby not affecting the equilibrium reaction a great deal. The majority of cattle are fed in the Plains states of the United States. These feedlots are nearly all outside open dirt pens. Pens are typically cleaned (i.e., manure removed) when cattle within the pens are sold and before a new lot of cattle being placed in the pen. That means that it is normal for manure to accumulate over a 120 - to $200-\mathrm{d}$ period.

Management and nutrition are factors in minimizing the $\mathrm{N}$ loss from animal manure. The methods discussed herein are reducing $\mathrm{N}$ intake, manipulating the route of excretion, manipulating the $\mathrm{C}: \mathrm{N}$ ratio of manure on the pen surface, acidification, and lastly, the impact of feeding by-products. In all of these experiments, a mass balance approach was used to determine the impact on $\mathrm{N}$ in manure and $\mathrm{N}$ lost. Retention of $\mathrm{N}$ in the animal as it gains BW to market was calculated from actual steer BW gains and NRC (1996) equations. Runoff was quantified and analyzed for N. Soil core samples were taken from the pen surface before and at the conclusion of studies (after manure removal). The cores were analyzed to account for $\mathrm{N}$ not removed or for soil $\mathrm{N}$ removal with the manure. Finally, manure was sampled, weighed, and composted. Loss of $\mathrm{N}$ is calculated as $\mathrm{N}$ excretion minus the quantity of $\mathrm{N}$ in manure, including correction for soil balance, and $\mathrm{N}$ in runoff.

\section{METHODS TO MANIPULATE THE FATE OF $\mathbf{N}$}

\section{Reducing $N$ Intake by Utilizing the MP System}

The MP system presented in the 1996 NRC allows us to more accurately formulate feedlot diets so that requirements are met but protein is not oversupplied. The MP system separates protein needs into degradable intake protein (DIP) needs by the rumen microorganisms and MP needs by the animal. The MP is the sum of microbial protein and undegradable intake protein (UIP) absorbed at the small intestine (NRC, 1996). The challenge is to just meet both requirements without overfeeding. This is especially challenging as the requirements change during the feeding period as cattle get larger. It is difficult to accurately supplement just enough protein to meet and not exceed the requirements.

Erickson and Klopfenstein (2001a) conducted 4 finishing trials, 2 with calf-fed steers and 2 with yearlings, to evaluate the impact of more accurate formulations (phase-fed) to conventional feeding practices on $\mathrm{N}$ volatilization. The conventional diet was kept constant throughout and contained $92.5 \%$ concentrate and 13.5\% CP. Phase-fed diets were also $92.5 \%$ concentrate and formulated to match DIP, UIP, and MP requirements throughout the feeding period.

Phase-fed steers excreted less $\mathrm{N}$ than control steers (Table 1). Nitrogen excretion to the pen surface was reduced by $22 \%$ with yearlings, whereas total $\mathrm{N}$ volatilized into the atmosphere was reduced by $32 \%$ for the phasefed diets compared with the conventional diet. Nitrogen excretion to the pen surface was reduced by $13 \%$ with calves, whereas total $\mathrm{N}$ volatilized into the atmosphere was reduced by $15 \%$ for the phase-fed diets compared with the conventional diet. Differences in N volatilization between the yearlings and calves are likely due to cooler temperatures during the calf-finishing studies (i.e., November to May) compared with the yearlingfinishing studies (i.e., May to October). Volatilization was greater (60 to $70 \%$ ) in the summer than in the winter $(40 \%)$. When weighted for time of year and cattle on feed at different times of the year, we calculated the average volatilization loss to be $50.8 \%$ of the $\mathrm{N}$ excreted for control and phase-fed diets (Erickson and Klopfenstein, 2001a). However, the actual amount of N volatilized in kilograms was markedly decreased by reducing $\mathrm{N}$ intake. Presumably, the observed decrease in $\mathrm{N}$ volatilization losses is directly related to decreasing the urinary $\mathrm{N}$ excreted. In these previous experiments, we presumed that no recycling of excess bypass protein (i.e., UIP) occurred. Late in the feeding period, there is a large excess of UIP. If that excess UIP is digested and the protein deaminated, then the excess ammonia will recycle to the rumen. Therefore, Quinn et al. (2006a,b) fed diets even further reduced in protein to determine the impact on performance and on $\mathrm{N}$ mass balance in the summer with yearlings (Quinn et al., 2006a) and with calf-fed steers in the winter (Quinn et al., 2006b). With yearlings and calf-fed steers, G:F was not different or improved by phase-feeding and accounting for recycled N (Table 2). Similar to previous studies, feeding less protein decreased $\mathrm{N}$ intake and volatilization without affecting manure $\mathrm{N}$ (Table 2).

\section{Increased $C$ on the Pen Surface}

Adding $\mathrm{C}$ to the pen surface may increase the $\mathrm{C}: \mathrm{N}$ ratio of feedlot manure. The increase in $\mathrm{C}: \mathrm{N}$ ratio may 
Table 1. Performance and $\mathrm{N}$ intake, $\mathrm{N}$ in manure, and $\mathrm{N}$ lost for finishing yearlings and calves fed a conventional protein level or phase-fed multiple finishing diets to match protein requirements ${ }^{1}$

\begin{tabular}{|c|c|c|c|}
\hline \multirow[b]{2}{*}{ Item } & \multicolumn{2}{|c|}{ Treatment } & \multirow[b]{2}{*}{$P$-value } \\
\hline & Conventional & Phase-fed & \\
\hline \multicolumn{4}{|l|}{ Yearlings fed in summer ${ }^{2}$} \\
\hline DMI, $\mathrm{kg} / \mathrm{d}$ & 11.4 & 11.1 & 0.03 \\
\hline $\mathrm{ADG}, \mathrm{kg}$ & 1.81 & 1.85 & 0.27 \\
\hline G:F & 0.158 & 0.166 & 0.01 \\
\hline $\mathrm{N}$ intake, $\mathrm{kg} /$ steer & 33.1 & 27.0 & 0.01 \\
\hline $\mathrm{N}$ manure, $\mathrm{kg} / \mathrm{steer}$ & 7.6 & 8.5 & 0.39 \\
\hline $\mathrm{N}$ volatilized, $\mathrm{kg} /$ steer & 20.9 & 14.2 & 0.01 \\
\hline $\mathrm{N}$ lost, $\%$ of excreted $\mathrm{N}$ & 70.9 & 60.7 & \\
\hline \multicolumn{4}{|l|}{ Calves fed in winter/spring ${ }^{3}$} \\
\hline DMI, $\mathrm{kg} / \mathrm{d}$ & 9.22 & 9.40 & 0.21 \\
\hline $\mathrm{ADG}, \mathrm{kg}$ & 1.57 & 1.54 & 0.43 \\
\hline G:F & 0.170 & 0.164 & 0.04 \\
\hline $\mathrm{N}$ intake, $\mathrm{kg} /$ steer & 37.0 & 32.7 & 0.01 \\
\hline $\mathrm{N}$ manure, $\mathrm{kg} /$ steer & 18.1 & 15.9 & 0.24 \\
\hline $\mathrm{N}$ volatilized, $\mathrm{kg} /$ steer & 13.3 & 11.3 & 0.32 \\
\hline $\mathrm{N}$ lost, $\%$ of excreted $\mathrm{N}$ & 41.1 & 40.1 & \\
\hline
\end{tabular}

${ }^{1}$ Results are from Erickson and Klopfenstein (2001a).

${ }^{2}$ Two experiments with yearling steers fed an average of $132 \mathrm{~d}$ across years with 12 replications per treatment.

${ }^{3}$ Two experiments with calf-fed steers fed an average of $183 \mathrm{~d}$ with 12 replications per treatment.

trap more $\mathrm{N}$ because $\mathrm{C}$ is generally limited on pen surfaces. Dewes (1996) added straw (i.e., added C) to cattle manure and decreased $\mathrm{N}$ volatilization losses from 23.2 to $5.1 \%$ over $14 \mathrm{~d}$. Lory et al. (2002) added sawdust to open-dirt feedlots and reduced $\mathrm{N}$ volatilization losses from pens by $21 \%$.

Bierman et al. (1999) studied the effect of level and source of dietary fiber on mass balance of nutrients on feedlot pens. Bierman et al. (1999) fed an all-concentrate diet to minimize OM excreted. A $7.5 \%$ addition of roughage increased fecal output and adding $41.5 \%$ wet corn gluten feed further increased fecal output. The authors hypothesized that fiber digestion in the hind gut would shift N excretion from urine to feces. Only $19 \%$ of the $\mathrm{N}$ was excreted in the feces by cattle fed the allconcentrate diet, whereas $31 \%$ was excreted by cattle fed the wet corn gluten feed diet. The cattle on the allconcentrate diet produced about $88 \mathrm{~kg}$ of manure OM for $87 \mathrm{~d}$ while in pens. The cattle fed wet corn gluten feed produced about $189 \mathrm{~kg}$ of OM available for clean-

Table 2. Performance and $\mathrm{N}$ mass balance when steers were phase-fed and $\mathrm{N}$ recycling was assumed compared with a conventional protein level

\begin{tabular}{|c|c|c|c|}
\hline \multirow[b]{2}{*}{ Item } & \multicolumn{2}{|c|}{ Treatment } & \multirow[b]{2}{*}{$P$-value } \\
\hline & Conventional & Phase-fed & \\
\hline \multicolumn{4}{|l|}{ Yearlings fed in summer ${ }^{1}$} \\
\hline DMI, kg/d & 10.5 & 10.0 & 0.08 \\
\hline $\mathrm{ADG}, \mathrm{kg}$ & 1.67 & 1.59 & 0.23 \\
\hline G:F & 0.159 & 0.159 & 0.88 \\
\hline $\mathrm{N}$ intake, $\mathrm{kg} /$ steer & 28.1 & 22.3 & 0.01 \\
\hline $\mathrm{N}$ manure, $\mathrm{kg} /$ steer & 6.76 & 5.81 & 0.35 \\
\hline $\mathrm{N}$ volatilized, $\mathrm{kg} /$ steer & 17.5 & 12.8 & 0.02 \\
\hline $\mathrm{N}$ lost, $\%$ of excreted $\mathrm{N}$ & 70.4 & 66.5 & 0.58 \\
\hline \multicolumn{4}{|c|}{ Calves fed in winter/spring ${ }^{2}$} \\
\hline DMI, kg/d & 9.99 & 9.76 & 0.20 \\
\hline $\mathrm{ADG}, \mathrm{kg}$ & 1.62 & 1.65 & 0.11 \\
\hline $\mathrm{G}: \mathrm{F}$ & 0.162 & 0.168 & 0.02 \\
\hline $\mathrm{N}$ intake, $\mathrm{kg} /$ steer & 35.9 & 33.0 & 0.01 \\
\hline $\mathrm{N}$ manure, $\mathrm{kg} /$ steer & 12.8 & 12.8 & 0.71 \\
\hline $\mathrm{N}$ volatilized, $\mathrm{kg} /$ steer & 16.2 & 13.3 & 0.11 \\
\hline $\mathrm{N}$ lost, $\%$ of excreted $\mathrm{N}$ & 53.7 & 48.8 & 0.44 \\
\hline
\end{tabular}

${ }^{1}$ Results from Quinn et al. (2006a) for yearlings fed $117 \mathrm{~d}$ with 6 replications per treatment.

${ }^{2}$ Results from Quinn et al. (2006b) for calf-fed steers fed $176 \mathrm{~d}$ with 6 replications per treatment. 
Table 3. Effect of dietary corn bran on $\mathrm{N}$ balance in the feedlot across seasons (expressed as $\mathrm{kg} /$ steer over the entire feeding periods unless noted $)^{1}$

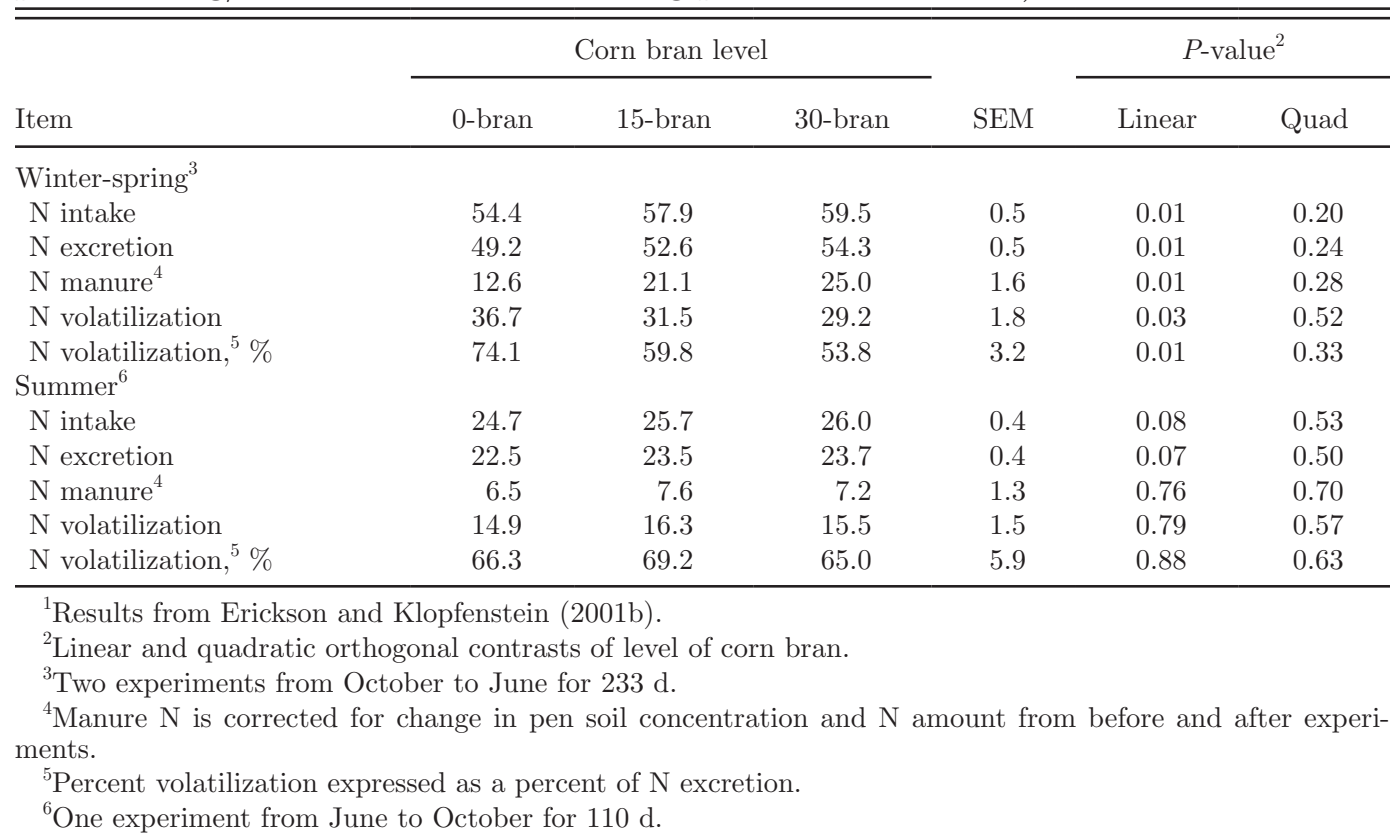

ing for those same days. The all-concentrate diet has appeared as good news in the past because less manure needed disposal. However, Bierman et al. (1999) showed that to be able to remove more $\mathrm{N}$ in the manure, it was necessary to remove more OM as well.

Another option explored recently is to add corn bran (i.e., digestible fiber portion of wet corn gluten feed) in place of corn in feedlot diets (Erickson and Klopfenstein, 2001b). This product composes approximately $50 \%$ of wet corn gluten feed but is probably solely responsible for the results Bierman et al. (1999) observed with increased manure N. Digestibility data indicate that increasing corn bran from 0 to $30 \%$ linearly decreases OM digestibility by $4.2 \%$ (Erickson and Klop-

Table 4. Performance and $\mathrm{N}$ mass balance of calves fed $167 \mathrm{~d}$ in the winter/spring months ${ }^{1}$

\begin{tabular}{|c|c|c|c|c|c|c|}
\hline \multirow[b]{2}{*}{ Item } & \multicolumn{4}{|c|}{ Treatment $^{2}$} & \multirow[b]{2}{*}{ SEM } & \multirow[b]{2}{*}{$P$-value ${ }^{3}$} \\
\hline & Control & $30 / 0$ & $30 / 15$ & $45 / 15$ & & \\
\hline \multicolumn{7}{|l|}{ Performance } \\
\hline DMI, kg/d & 10.5 & 11.0 & 11.4 & 10.7 & 0.2 & 0.06 \\
\hline $\mathrm{ADG}, \mathrm{kg}$ & 1.68 & 1.72 & 1.77 & 1.68 & 0.04 & 0.22 \\
\hline $\mathrm{G}: \mathrm{F}$ & 0.160 & 0.157 & 0.156 & 0.153 & 0.003 & 0.56 \\
\hline \multicolumn{7}{|l|}{$\mathrm{N}$ balance, $\mathrm{kg} /$ steer } \\
\hline $\mathrm{N}$ intake & $41.3^{\mathrm{a}}$ & $40.4^{\mathrm{a}}$ & $44.1^{\mathrm{b}}$ & $42.4^{\mathrm{ab}}$ & 0.7 & 0.02 \\
\hline $\mathrm{N}$ excretion ${ }^{4}$ & $35.7^{\mathrm{b}}$ & $34.6^{\mathrm{a}}$ & $38.1^{\mathrm{c}}$ & $36.6^{\mathrm{bc}}$ & 0.6 & 0.01 \\
\hline Fecal N & $9.92^{\mathrm{a}}$ & $12.3^{\mathrm{b}}$ & $13.5^{\mathrm{c}}$ & $12.5^{\mathrm{bc}}$ & 0.3 & $<0.01$ \\
\hline Manure N & $13.0^{\mathrm{a}}$ & $17.1^{\mathrm{b}}$ & $18.5^{\mathrm{b}}$ & $23.6^{\mathrm{c}}$ & 1.6 & $<0.01$ \\
\hline Runoff N & 0.089 & 0.025 & 0.006 & 0.004 & 0.027 & 0.20 \\
\hline $\mathrm{N}$ volatilization ${ }^{5}$ & $22.6^{\mathrm{a}}$ & $17.4^{\mathrm{bc}}$ & $19.7^{\mathrm{ab}}$ & $13.1^{\mathrm{c}}$ & 1.5 & 0.01 \\
\hline $\mathrm{N}$ loss ${ }^{6} \%$ & $63.7^{\mathrm{a}}$ & $50.7^{\mathrm{b}}$ & $51.8^{\mathrm{b}}$ & $35.8^{\mathrm{c}}$ & 4.1 & 0.01 \\
\hline \multirow{2}{*}{\multicolumn{7}{|c|}{$\begin{array}{l}{ }^{a-c} \text { Means within row with different superscripts differ }(P<0.05) \text {. } \\
{ }^{1} \text { Results from Saver et al. }(2004) \text {. }\end{array}$}} \\
\hline & & & & & & \\
\hline \multirow{4}{*}{\multicolumn{7}{|c|}{$\begin{array}{l}{ }^{2} \text { Treatments }(\mathrm{DM} \text { basis): control }=\text { dry-rolled corn-based diet; } 30 / 0=\text { dry-rolled corn replaced with } 30 \% \\
\text { bran and } 0 \% \text { steep; } 30 / 15=\text { dry-rolled corn and molasses replaced with } 30 \% \text { bran and } 15 \% \text { steep; } 45 / 15= \\
\text { dry-rolled corn and molasses replaced with } 45 \% \text { bran and } 15 \% \text { steep. } \\
{ }^{3} \text { Data were analyzed using a protected } F \text {-test where numbers represent } P \text {-value for variation due to treat- } \\
\text { ment. } \\
{ }^{4} \text { Calculated as } \mathrm{N} \text { intake }-\mathrm{N} \text { retention where } \mathrm{N} \text { retention was calculated using the NRC (1996) net protein } \\
\text { and energy equations. }\end{array}$}} \\
\hline & & & & & & \\
\hline & & & & & & \\
\hline & & & & & & \\
\hline${ }^{5} \mathrm{~N}$ lost $=\mathrm{N}$ ex & are $\mathrm{N}-$ & & & & & \\
\hline
\end{tabular}


Table 5. Performance and $\mathrm{N}$ mass balance of yearlings fed $126 \mathrm{~d}$ in the summer months $^{1}$

\begin{tabular}{|c|c|c|c|c|c|c|}
\hline \multirow[b]{2}{*}{ Item } & \multicolumn{4}{|c|}{ Treatment $^{2}$} & \multirow[b]{2}{*}{ SEM } & \multirow[b]{2}{*}{$P$-value ${ }^{3}$} \\
\hline & Control & $30 / 0$ & $30 / 15$ & $45 / 15$ & & \\
\hline \multicolumn{7}{|l|}{ Performance } \\
\hline DMI, kg/d & $10.9^{\mathrm{a}}$ & $11.6^{\mathrm{b}}$ & $11.8^{\mathrm{b}}$ & $11.5^{\mathrm{b}}$ & 0.11 & $<0.01$ \\
\hline $\mathrm{ADG}, \mathrm{kg}$ & 1.59 & 1.57 & 1.71 & 1.65 & 0.04 & 0.07 \\
\hline $\mathrm{G}: \mathrm{F}$ & $0.146^{\mathrm{b}}$ & $0.135^{\mathrm{a}}$ & $0.144^{\mathrm{b}}$ & $0.143^{\mathrm{b}}$ & 0.003 & 0.05 \\
\hline \multicolumn{7}{|l|}{$\mathrm{N}$ balance, $\mathrm{kg} /$ steer } \\
\hline $\mathrm{N}$ intake & $34.1^{\mathrm{a}}$ & $37.8^{\mathrm{c}}$ & $36.8^{\mathrm{bc}}$ & $36.3^{\mathrm{b}}$ & 0.3 & $<0.01$ \\
\hline $\mathrm{N}$ excretion ${ }^{4}$ & $29.1^{\mathrm{a}}$ & $32.8^{\mathrm{c}}$ & $31.4^{\mathrm{b}}$ & $31.1^{\mathrm{b}}$ & 0.3 & $<0.01$ \\
\hline Fecal N & $6.72^{\mathrm{a}}$ & $9.21^{\mathrm{b}}$ & $9.94^{\mathrm{c}}$ & $9.78^{\mathrm{c}}$ & 0.13 & $<0.01$ \\
\hline Manure N & $10.1^{\mathrm{a}}$ & $13.5^{\mathrm{b}}$ & $13.0^{\mathrm{b}}$ & $13.2^{\mathrm{b}}$ & 0.7 & 0.01 \\
\hline Runoff N & 1.04 & 0.75 & 1.47 & 0.67 & 0.21 & 0.09 \\
\hline $\mathrm{N}$ volatilization ${ }^{5}$ & 18.5 & 18.9 & 17.7 & 17.5 & 1.0 & 0.69 \\
\hline $\mathrm{N}$ loss ${ }^{6} \%$ & 63.5 & 57.8 & 56.2 & 56.4 & 3.0 & 0.29 \\
\hline \multicolumn{7}{|c|}{$\begin{array}{l}{ }^{1} \text { Results from Sayer et al. }(2004) . \\
{ }^{2} \text { Treatments }(\mathrm{DM} \text { basis): control }=\text { dry-rolled corn-based diet with no by-product inclusion; } 30 / 0=\text { dry- } \\
\text { rolled corn replaced with } 30 \% \text { bran and } 0 \% \text { steep; } 30 / 15=\text { dry-rolled corn and molasses replaced with } 30 \% \\
\text { bran and } 15 \% \text { steep; } 45 / 15=\text { dry-rolled corn and molasses replaced with } 45 \% \text { bran and } 15 \% \text { steep. } \\
{ }^{3} \text { Data were analyzed using a protected } F \text {-test for variation due to treatment. } \\
{ }^{4} \text { Calculated as N intake - N retention, where N retention was calculated using the NRC (1996) net protein } \\
\text { and energy equations. }\end{array}$} \\
\hline
\end{tabular}

fenstein, 2001b). Less OM digestibility means more C (approximately $0.8 \mathrm{~kg} /$ steer daily) excreted by cattle fed $30 \%$ corn bran (30-bran) compared with control cattle (0-bran). Yearling cattle were fed from October through the following September. Increasing corn bran decreased feed efficiency (less digestibility), as predicted. However, more $\mathrm{N}$ was trapped in manure by adding dietary corn bran, which increased linearly as corn bran increased from 0 to $30 \%$ of diet DM from October to June (Table 3).

Because more $\mathrm{N}$ was removed in manure, less $\mathrm{N}$ was lost to volatilization. Volatile losses were decreased by
$27 \%$ when bran was added up to $30 \%$ of diet DM. Feeding identical diets to similar types of cattle from June to September did not have an impact on $\mathrm{N}$ in manure or $\mathrm{N}$ lost (Table 3). Presumably, the N volatilization losses are rapid and large during the warm, summer months and extra $\mathrm{C}$ had little value in trapping more $\mathrm{N}$. This was similar to results reported by Adams et al. (2004) where adding corn bran decreased $\mathrm{N}$ volatilization losses from 49 to $29 \%$ (expressed as a \% of $\mathrm{N}$ excreted) compared with corn-based diets during the winter-spring feeding periods. Feeding corn bran in their study to increase C had no positive impact on $\mathrm{N}$ volatilization losses during

Table 6. Nitrogen mass balance and amount of manure DM and OM per steer across $2 \mathrm{yr}^{1}$ expressed in kilograms per steer for pens cleaned monthly or once at the end of the feeding period ${ }^{2}$

\begin{tabular}{|c|c|c|c|c|c|c|c|c|}
\hline \multirow[b]{2}{*}{ Item } & \multicolumn{4}{|c|}{ Year 1} & \multicolumn{4}{|c|}{ Year 2} \\
\hline & Monthly & End & SEM & $P$-value & Monthly & End & SEM & $P$-value \\
\hline $\mathrm{OM}$ & 200 & 104 & 10 & $<0.01$ & 204 & 122 & 10 & $<0.01$ \\
\hline $\mathrm{N}$ intake ${ }^{3}$ & 30.4 & 30.4 & 0.4 & 0.91 & 25.8 & 26.2 & 0.45 & 0.08 \\
\hline $\mathrm{N}$ retention ${ }^{4}$ & 3.9 & 3.9 & 0.1 & 0.73 & 4.0 & 3.8 & 0.1 & $<0.01$ \\
\hline $\mathrm{N}$ lost ${ }^{6}$ & 16.7 & 20.7 & 0.7 & $<0.01$ & 12.1 & 15.2 & 0.9 & $<0.01$ \\
\hline $\mathrm{N}$ loss, ${ }^{7} \%$ & 63.6 & 78.4 & 1.4 & $<0.01$ & 55.5 & 68.0 & 1.7 & $<0.01$ \\
\hline
\end{tabular}

${ }^{1}$ Yr 1 was $140 \mathrm{~d}$ and yr 2 was $121 \mathrm{~d}$ for mass balance.

${ }^{2}$ Results from Wilson et al. (2004).

${ }^{3}$ Calculated using DMI and N concentration in the diet.

${ }^{4}$ Calculated using NRC (1996) net protein and NE equations.

${ }^{5}$ Calculated as $\mathrm{N}$ intake $-\mathrm{N}$ retention.

${ }^{6}$ Calculated as $\mathrm{N}$ excretion - manure N.

${ }^{7}$ Calculated as $\mathrm{N}$ lost divided by $\mathrm{N}$ excretion and expressed as a percentage of $\mathrm{N}$ excreted. 
Table 7. Effect of manure storage method on nutrient concentrations and recoveries during yr $1^{1}$

\begin{tabular}{|c|c|c|c|c|c|c|c|c|c|c|c|c|}
\hline \multirow[b]{2}{*}{ Item } & \multicolumn{5}{|c|}{ Stockpile $^{2}$} & \multicolumn{5}{|c|}{ Compost $^{2}$} & \multirow[b]{2}{*}{ SEM } & \multirow[b]{2}{*}{$P$-value } \\
\hline & 0 & 42 & 69 & 83 & 104 & 0 & 42 & 69 & 83 & 104 & & \\
\hline DM, \% & 72.5 & 75.6 & 74.3 & 74.2 & 73.8 & 71.2 & 73.2 & 70.0 & 70.0 & 72.6 & 2.8 & 0.78 \\
\hline DM recovery, \% & 100 & 89.1 & 87.2 & 85.7 & 85.7 & 100 & 86.3 & 82.3 & 81.8 & 81.4 & 1.5 & 0.14 \\
\hline OM recovery, \% & $100^{\mathrm{a}}$ & $63.4^{\mathrm{b}}$ & $57.1^{\text {bc }}$ & $51.8^{\mathrm{c}}$ & $51.0^{\mathrm{b}}$ & $100^{\mathrm{a}}$ & $53.9^{\mathrm{c}}$ & $40.1^{\mathrm{d}}$ & $38.6^{\mathrm{d}}$ & $37.2^{\mathrm{d}}$ & 4.0 & $<0.01$ \\
\hline Total N recovery, \% & $100^{\mathrm{a}}$ & $87.5^{\mathrm{b}}$ & $83.0^{\mathrm{bc}}$ & $82.9^{\mathrm{bc}}$ & $85.7^{\mathrm{bc}}$ & $100^{\mathrm{a}}$ & $78.5^{\mathrm{c}}$ & $64.0^{\mathrm{d}}$ & $59.4^{\mathrm{de}}$ & $56.4^{\mathrm{e}}$ & 4.1 & $<0.01$ \\
\hline Total N, g/kg of DM & $14.2^{\mathrm{a}}$ & $12.4^{\mathrm{abc}}$ & $11.8^{\mathrm{c}}$ & $11.8^{\mathrm{c}}$ & $12.2^{\mathrm{bc}}$ & $14.6^{\mathrm{a}}$ & $11.5^{\mathrm{c}}$ & $9.3^{\mathrm{d}}$ & $8.7^{\mathrm{d}}$ & $8.2^{\mathrm{d}}$ & 1.0 & $<0.01$ \\
\hline $\mathrm{NH}_{4}, \%$ total $\mathrm{N}$ & $7.9^{\mathrm{c}}$ & $18.2^{\mathrm{ab}}$ & $15.8^{\mathrm{b}}$ & $17.1^{\mathrm{ab}}$ & $19.0^{\mathrm{a}}$ & $7.3^{\mathrm{c}}$ & $20.5^{\mathrm{a}}$ & $3.7^{\mathrm{d}}$ & $7.2^{\mathrm{c}}$ & $4.2^{\mathrm{d}}$ & 0.9 & $<0.01$ \\
\hline
\end{tabular}

the summer $(P=0.52)$, with losses of 59 and $53 \%$ for corn and bran diets, respectively. The same was true when they compared adding sawdust (i.e., bedding) in that adding sawdust was effective in the winter-spring at reducing $\mathrm{N}$ volatilization losses (49\% decreased to $27 \%$ ) but had no effect on $\mathrm{N}$ volatilization losses during the summer months (59 to $62 \%$ ). One negative consequence of decreasing diet digestibility with corn bran was a decrease in G:F. Therefore, Sayer et al. (2004) fed different levels of corn bran to decrease digestibility; however, they added steep liquor (i.e., liquid stream within wet milling corn processing plants) to enhance performance while still decreasing diet digestibility. In essence, feeding combinations of steep and bran is similar to some forms of corn gluten feed that consist of bran and steep. Sayer et al. (2004) was successful at enhancing performance by adding steep at $15 \%$ inclusion during winter-spring months as well as summer months (Table 4 and 5). Similar to previous research with corn bran, $\mathrm{N}$ volatilization losses were decreased during the winter-spring months by feeding corn bran at 30 or $45 \%$ with $15 \%$ steep added. Feeding corn bran and steep at 45 and $15 \%$, respectively, decreased $\mathrm{N}$ volatilization losses from $64 \%$ in the control animals to $36 \%$ of $\mathrm{N}$ excreted (Table 4). However, feeding bran with or without steep did not affect $\mathrm{N}$ volatilization losses during the summer months (Table 5).

\section{Cleaning Frequency and Decreased Oxygen Exposure}

Monthly Cleaning vs. Cleaning After Marketing. Cleaning frequency was evaluated during summer months by Wilson et al. (2004). Either monthly or end cleaning were evaluated. End cleaning refers to cleaning pens at the end of the feeding period. Monthly cleaning was performed every $28 \mathrm{~d}$ throughout the feeding period. In 2001, 432 yearling steers in 54 open feedlot pens receiving the same diet were utilized. The diet consisted of $40 \%$ wet corn gluten feed, $33 \%$ highmoisture corn, $7 \%$ alfalfa hay, and $5 \%$ supplement. In 2002, 384 yearling steers in 48 pens were utilized with all pens receiving the same diet. The diet consisted of $35 \%$ wet corn gluten feed, $55 \%$ high moisture corn, $5 \%$ corn silage, $2 \%$ alfalfa hay, and $3 \%$ supplement. The pen space per steer was equal in both years with $28 \mathrm{~m}^{2}$ per head. Pens were designated in each experiment as monthly cleaning or end cleaning. Within each cleaning frequency, collected manure was composted. Manure collected from pens was sampled at cleaning and weighed. Manure analysis was utilized to evaluate DM, $\mathrm{OM}$, and $\mathrm{N}$ recovery from the feedlot pen over the entire feeding period.

The amounts of DM and $\mathrm{N}$ removed were increased if pens were cleaned monthly compared with cleaning at

Table 8. Effect of manure storage method on nutrient concentrations and recoveries during yr $2^{1}$

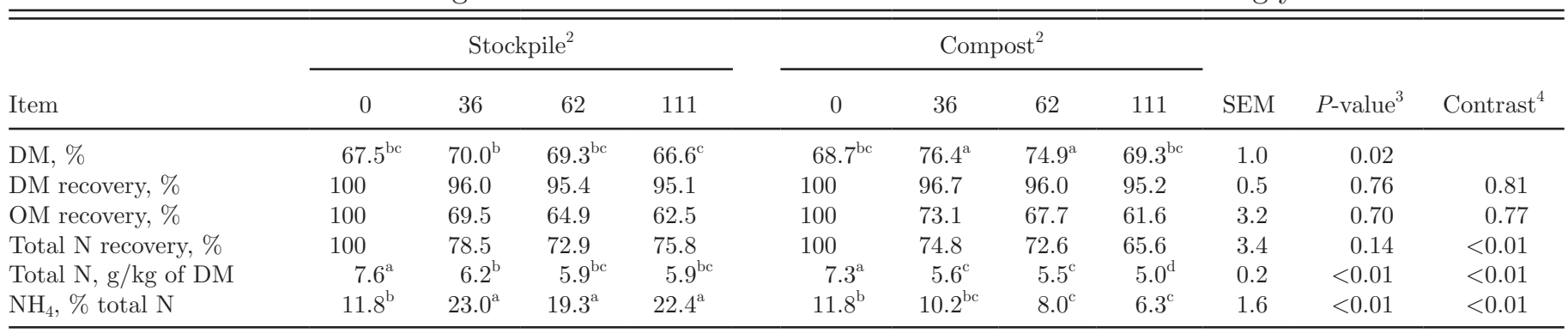

\footnotetext{
${ }^{\mathrm{a}-\mathrm{d}}$ Within a row, means without a common superscript letter differ $(P<0.05)$.

${ }^{1}$ Results from Luebbe et al. (2008a).

${ }^{2}$ Sampling date from pen cleaning.

${ }^{3} F$-test statistic for storage method $\times$ time interaction.

${ }^{4}$ Comparison of compost vs. stockpiling on d 111 for yr 2 only.
} 
Table 9. Growth performance for steers fed during summer ${ }^{1}$ and winter ${ }^{2}$ and fed 0,15 , or $30 \%$ wet distillers grains plus solubles (WDGS; DM basis)

\begin{tabular}{|c|c|c|c|c|c|}
\hline \multirow[b]{2}{*}{ Item } & \multicolumn{3}{|c|}{ Treatment $^{3}$} & \multirow[b]{2}{*}{ SEM } & \multirow[b]{2}{*}{$P$-value ${ }^{4}$} \\
\hline & Control & 15 & 30 & & \\
\hline \multicolumn{6}{|l|}{ Summer } \\
\hline DMI, ${ }^{5} \mathrm{~kg} / \mathrm{d}$ & 11.4 & 11.8 & 11.8 & 0.2 & 0.13 \\
\hline $\mathrm{ADG},{ }^{5} \mathrm{~kg}$ & $1.80^{\mathrm{a}}$ & $1.94^{\mathrm{b}}$ & $1.91^{\mathrm{b}}$ & 0.10 & 0.05 \\
\hline $\mathrm{G}: \mathrm{F}$ & 0.158 & 0.164 & 0.162 & 0.004 & 0.38 \\
\hline \multicolumn{6}{|l|}{ Winter } \\
\hline $\mathrm{DMI},{ }^{5} \mathrm{~kg} / \mathrm{d}$ & 9.3 & 9.8 & 10.0 & 0.3 & 0.10 \\
\hline $\mathrm{ADG},{ }^{5} \mathrm{~kg}$ & 1.61 & 1.67 & 1.73 & 0.05 & 0.12 \\
\hline $\mathrm{G}: \mathrm{F}$ & 0.172 & 0.174 & 0.177 & 0.003 & 0.27 \\
\hline \multicolumn{6}{|c|}{${ }^{\mathrm{a}, \mathrm{b}}$ Within a row, means without a common superscript letter differ $(P<0.05)$. } \\
\hline \multicolumn{6}{|c|}{${ }^{1}$ Results from Luebbe et al. (2007a). } \\
\hline \multicolumn{6}{|c|}{${ }^{2}$ Results from Luebbe et al. (2007b). } \\
\hline \multicolumn{6}{|c|}{${ }^{3}$ Dietary treatments: control $=$ corn-based diet with no WDGS; $15=15 \%$ WDGS (DM basis); $30=30 \%$} \\
\hline \multicolumn{6}{|c|}{ WDGS (DM basis). } \\
\hline \multicolumn{6}{|c|}{${ }^{4} F$-test statistic for dietary treatment. } \\
\hline
\end{tabular}

the end of the feeding period during summer (Table 6). By cleaning pens every month, $\mathrm{N}$ removal was increased $3.9 \mathrm{~kg}$ per steer or a $69.0 \%$ increase above manure $\mathrm{N}$ removed at the end of the feeding period in 2001. Monthly cleaning in 2002 increased manure $\mathrm{N}$ removal $2.5 \mathrm{~kg}$ per steer or a $34.8 \%$ increase above manure $\mathrm{N}$ removed at the end of the feeding period. If manure is allowed to collect on pen surfaces during the entire feeding period, more $\mathrm{N}$ was exposed to the environment and available for volatilization. Monthly cleaning reduced the total N loss to the environment by an average of $14 \%$.

Stockpiling Manure vs. Composting. Spreading fresh manure that was just collected from pens is not a common method of handling manure because

Table 10. Effect of dietary treatment on $\mathrm{N}$ mass balance ${ }^{1}$ during summer ${ }^{2}$ and winter ${ }^{3}$ for steers fed 0,15 , or $30 \%$ wet distillers grains plus solubles (WDGS; DM basis)

\begin{tabular}{|c|c|c|c|c|c|}
\hline \multirow[b]{2}{*}{ Item } & \multicolumn{3}{|c|}{ Treatment $^{4}$} & \multirow[b]{2}{*}{ SEM } & \multirow[b]{2}{*}{$P$-value ${ }^{5}$} \\
\hline & Control & 15 & 30 & & \\
\hline \multicolumn{6}{|l|}{ Summer } \\
\hline $\mathrm{N}$ intake $^{6}$ & $29.0^{\mathrm{a}}$ & $35.5^{\mathrm{b}}$ & $42.9^{\mathrm{c}}$ & 1.2 & $<0.01$ \\
\hline $\mathrm{N}$ excretion ${ }^{6,7}$ & $24.3^{\mathrm{a}}$ & $30.5^{\mathrm{b}}$ & $38.1^{\mathrm{c}}$ & 1.1 & $<0.01$ \\
\hline Manure $\mathrm{N}^{8}$ & 8.99 & 9.67 & 10.03 & 5.0 & 0.89 \\
\hline $\mathrm{N}$ runoff & 1.18 & 0.86 & 1.54 & 1.2 & 0.53 \\
\hline $\mathrm{N}$ lost $^{6}$ & $14.2^{\mathrm{a}}$ & $20.0^{\mathrm{b}}$ & $26.5^{\mathrm{c}}$ & 5.1 & $<0.01$ \\
\hline $\mathrm{N}$ loss, ${ }^{9} \%$ & 58.1 & 65.6 & 69.6 & 7.2 & 0.15 \\
\hline OM removed ${ }^{6}$ & $98^{\mathrm{a}}$ & $108^{\mathrm{a}}$ & $156^{\mathrm{b}}$ & 45 & 0.04 \\
\hline \multicolumn{6}{|l|}{ Winter } \\
\hline $\mathrm{N}$ intake ${ }^{6}$ & $31.5^{\mathrm{a}}$ & $36.2^{\mathrm{b}}$ & $44.7^{\mathrm{c}}$ & 1.6 & $<0.01$ \\
\hline $\mathrm{N}$ excretion ${ }^{6,7}$ & $25.9^{\mathrm{a}}$ & $30.5^{\mathrm{b}}$ & $38.7^{\mathrm{c}}$ & 1.6 & $<0.01$ \\
\hline Manure $\mathrm{N}^{6,8}$ & $11.4^{\mathrm{a}}$ & $10.9^{\mathrm{a}}$ & $17.3^{\mathrm{b}}$ & 5.2 & 0.04 \\
\hline $\mathrm{N}$ runoff & 0.47 & 0.54 & 0.78 & 0.36 & 0.18 \\
\hline $\mathrm{N}$ lost $^{6}$ & $14.0^{\mathrm{a}}$ & $19.1^{\mathrm{b}}$ & $20.7^{\mathrm{b}}$ & 4.6 & 0.03 \\
\hline $\mathrm{N} \mathrm{loss},{ }^{9} \%$ & 55.1 & 63.8 & 55.0 & 6.8 & 0.37 \\
\hline OM removed ${ }^{6}$ & 159 & 203 & 218 & 58 & 0.12 \\
\hline
\end{tabular}


crop acres are usually unavailable for spreading manure when pens are cleaned. Therefore, feedlots have 2 options for storing manure before application, which include aerobic composting and anaerobic stockpiling. Stockpiled manure often has more total N compared with composted manure but also has more ammonium $\mathrm{N}$. If $\mathrm{N}$ is lost before manure is incorporated into the soil in a crop field after application, there may not be a net benefit to stockpiling. Aerobic composting of manure decreases the amount of material that needs to be hauled to the field and also reduces odor. However, composting manure increases cost due to a larger area of land needed for control of runoff and the equipment and extra management of compost windrows. These management and storage options have a large impact on gas emissions, as well as amount and type of nutrients available to crops. The objective of this research was to compare anaerobic stockpiling and aerobic composting manure storage methods on nutrient recovery.

Luebbe et al. (2008a,b) compared stockpiling to composting using manure from pens all handled similarly and on similar diets. Compost was turned approximately every 2 wk. In the event of precipitation which prevents turning, compost was turned as soon as possible after 2 wk. Both types were sampled at those times. Across both years, stockpiling resulted in greater total $\mathrm{N}$ recovered in manure and available for crops (Tables 7 and 8).

\section{Impact of Distiller Grains Feeding}

Distillers grains, particularly wet distillers grains plus solubles (WDGS), is becoming a more popular feed in place of corn for finishing cattle. Distillers are generally $30 \%$ protein. Therefore, when dietary inclusion of distillers grains increases in place of corn, dietary protein is increased (17 to $22 \%$ of diet DM). Feeding WDGS improves performance and is equal to or greater in energy value than corn, depending on type of distillers grains, type of corn processing, and inclusion level (Klopfenstein et al., 2008). However, feeding distillers grains also decreases digestibility due to the greater fiber content relative to corn (Corrigan et al., 2009; Vander Pol et al., 2009), which may act similar to previous research discussed evaluating diets with less digestibility. Therefore, Luebbe et al. (2007a,b) conducted a 1-yr-long mass balance experiment to determine the impact of feeding 0, 15, or 30\% WDGS in place of corn. Cattle fed WDGS had increased ADG and G:F, which are typical responses (Table 9). As WDGS inclusion increased, N intake and excretion increased (Table 10). The response of feeding WDGS on N volatilization losses was variable by season. During the winter-spring feeding period, the extra $\mathrm{N}$ excretion from feeding WDGS resulted in both an increase in manure $\mathrm{N}$ and an increase in amount of $\mathrm{N}$ volatilization losses in kilograms per steer. When $\mathrm{N}$ volatilization losses were expressed as a percentage of $\mathrm{N}$ excretion, no differences were detected across WDGS levels. During the summer months, feeding WDGS in- creased $\mathrm{N}$ excretion and $\mathrm{N}$ volatilization losses whether expressed as amount lost $(\mathrm{kg} /$ steer $)$ or as a percentage of $\mathrm{N}$ excretion (Table 10).

\section{CONCLUSIONS}

The excretion of $\mathrm{N}$ can be reduced from current levels if the MP system is utilized. There is a limit to how much we can reduce $\mathrm{NH}_{3}$ emissions through nutrition. Carbon added to pens has variable responses on $\mathrm{N}$ volatilization losses, but appears to have value whether added by feeding diets less in digestibility or adding $\mathrm{C}$ (i.e., bedding) during the winter. Other means, such as alternative waste handling systems, may be necessary to further reduce ammonia emissions.

\section{LITERATURE CITED}

Adams, J. R., T. B. Farran, G. E. Erickson, T. J. Klopfenstein, C. N. Macken, and C. B. Wilson. 2004. Effect of organic matter addition to the pen surface and pen cleaning frequency on nitrogen balance in open feedlots. J. Anim. Sci. 82:2153-2163.

Bierman, S., G. E. Erickson, T. J. Klopfenstein, R. A. Stock, and D. H. Shain. 1999. Evaluation of nitrogen and organic matter balance in the feedlot as affected by level and source of dietary fiber. J. Anim. Sci. 77:1645-1653.

Corrigan, M. E., G. E. Erickson, T. J. Klopfenstein, M. K. Luebbe, K. J. Vander Pol, N. F. Meyer, C. D. Buckner, S. J. Vanness, and K. J. Hanford. 2009. Effect of corn processing method and corn wet distillers grains plus solubles inclusion level in finishing steers. J. Anim. Sci. 87:3351-3362.

Dewes, T. 1996. Effect of $\mathrm{pH}$, temperature, amount of litter and storage density on ammonia emissions from stable manure. J. Agric. Sci. (Camb.) 127:501-509.

Erickson, G. E., and T. J. Klopfenstein. 2001a. Managing N inputs and the effect on $\mathrm{N}$ volatilization following excretion in opendirt feedlots in Nebraska. Nitrogen in the Environment, The Scientific World, 1(S1):830-835. http://www.thescientificworld. com Accessed Jun. 15, 2002.

Erickson, G. E., and T. J. Klopfenstein. 2001b. Nutritional methods to decrease $\mathrm{N}$ volatilization from open-dirt feedlots in $\mathrm{Ne}-$ braska. Nitrogen in the Environment, The Scientific World, 1(S1):836-843. http://www.thescientificworld.com Accessed Jun. 15, 2002.

Klopfenstein, T. J., G. E. Erickson, and V. R. Bremer. 2008. BOARD-INVITED REVIEW: Use of distillers by-products in the beef cattle feeding industry. J. Anim. Sci. 86:1223-1231.

Lory, J., J. Adams, B. Eghball, T. Klopfenstein, and J. F. Powers. 2002. Effect of sawdust or acid application to pen surface on nitrogen losses from open-dirt feedlots. Nebr. Beef Cattle Rep. MP 79-A.

Luebbe, M. K., G. E. Erickson, T. J. Klopfenstein, and J. R. Benton. 2008a. Aerobic composting or anaerobic stockpiling of beef feedlot manure. J. Anim. Sci. 86(E-Suppl. 2):323. (Abstr.)

Luebbe, M. K., G. E. Erickson, T. J. Klopfenstein, and M. A. Greenquist. 2007a. Effect of modified wet distillers grains level on feedlot cattle performance and nitrogen mass balance. J. Anim. Sci. 85(Suppl. 1):409. (Abstr.)

Luebbe, M. K., G. E. Erickson, T. J. Klopfenstein, and M. A. Greenquist. 2007b. Effect of wet distillers grains level on feedlot cattle performance and nitrogen mass balance. J. Anim. Sci. 85(Suppl. 2):130. (Abstr.)

Luebbe, M. K., G. E. Erickson, T. J. Klopfenstein, and M. A. Greenquist. 2008b. Aerobic composting or anaerobic stockpiling of feedlot manure. J. Anim. Sci. 86(E-Suppl. 3):102. (Abstr.)

Mobley, H. L., M. D. Island, and R. P. Hausinger. 1995. Molecular biology of microbial ureases. Microbiol. Rev. 59:451-480. 
NRC. 1996. Nutrient Requirements of Beef Cattle. 7th ed. Natl. Acad. Press, Washington, DC.

Quinn, S., G. Erickson, T. Klopfenstein, R. Stowell, and K. Vander Pol. 2006a. Effect of phase feeding protein on cattle performance and nitrogen mass balance in the summer. J. Anim. Sci. 84(Suppl. 1):121. (Abstr.)

Quinn, S., G. Erickson, T. Klopfenstein, R. Stowell, K. Vander Pol, and D. Sherwood. 2006b. Effect of phase feeding protein on cattle performance and nitrogen mass balance. J. Anim. Sci. 84(Suppl. 2):132. (Abstr.)

Sayer, K. M., G. E. Erickson, T. J. Klopfenstein, C. N. Macken, and K. J. Vander Pol. 2004. Effect of corn bran and steep inclusion in finishing diets on performance and nitrogen balance of open dirt feedlots. J. Anim. Sci. 82(Suppl. 1):158. (Abstr.)
US EPA. 2004. Air Quality Criteria for Particulate Matter (Final Report, Oct 2004). U.S. Environmental Protection Agency, Washington, DC, EPA 600/P-99/002aF-bF. http://oaspub. epa.gov/eims/eimscomm.getfile?p_download_id=435946 Accessed Dec. 23, 2009.

Vander Pol, K. J., M. K. Luebbe, G. I. Crawford, G. E. Erickson, and T. J. Klopfenstein. 2009. Performance and digestibility characteristics of finishing diets containing distillers grains, composites of corn processing coproducts, or supplemental corn oil. J. Anim. Sci. 87:639-652.

Wilson, C. B., G. E. Erickson, C. N. Macken, and T. J. Klopfenstein. 2004. Impact of cleaning frequency on nitrogen balance in open feedlot pens. Nebr. Beef Cattle Rep. MP 80-A:72. 